\title{
Risk of Hepatic Encephalopathy in Diabetic Decompensated Liver Diseased Patients with Post- HCV Liver cirrhosis
}

\author{
Ghada A Salem, Amal A Jouda \\ Tropical Medicine Department, Faculty of Medicine, Zagazig University, Egypt
}

Corresponding Author: Ghada A Salem

E mail:ghadasalem69@ gmail.com

Key words:

Diabetes mellitus, hepatic encephalopathy, $\mathrm{HCV}$, HBAlc
Background and study aim: Hepatic encephalopathy (HE) is a complex and variable neuropsychiatric syndrome that is seen in patients with acute and chronic liver diseases. Diabetes mellitus (DM) is more prevalent in patients with post $\mathrm{HCV}$ cirrhosis. Because diabetes mellitus may be associated with delayed gastrointestinal transit and promoting constipation, increasing intestinal bacterial overgrowth and increasing glutaminase activity, we speculated that its presence in patients with $\mathrm{HCV}$ related cirrhosis would predispose to and exacerbate hepatic encephalopathy.

Patients and Methods: This study included 264 patients with severely decompensated post-HCV cirrhosis, 132 diabetic cirrhotic patients and 132 non-diabetic cirrhotic patients as control group. History is taken for all patients regarding the number of attacks of encephalopathy he experienced in the past three months, the duration of diabetes and the anti-diabetic medication he uses. All patients in the study performed liver function tests, abdominal ultrasound, complete blood count and HBA1c level for diabetic patients as well as psychometric tests for hepatic coma.
Results: Diabetic patients had higher frequency of all grades of hepatic encephalopathy mean number of attacks for each patient in the past three months is $1.9 \pm 0.3$ vs $0.8 \pm 0.1$ in non-diabetics with unclear precipitating factor in $43 \%$ of diabetic patients versus $23 \%$ in non-diabetic patients. Patients on oral hypoglycemic drugs represented $14.3 \%$ of diabetic patients. Patients with HBA1c $>11 \%$ were $43 \%$ among patients on oral hypoglycemic drugs vs $23 \%$ with insulin. Patients on oral hypoglycemic drugs had higher frequency of hepatic coma. The mean number of attacks experienced by each patient rises with increased concentration of HBA1c from $0.8 \pm 0.2$ at level $<7 \%$ to $6.4 \pm 3$ for level $>11 \%$. The mean number of attacks increased with the duration of diabetes from $1 \pm 0.4$ for $<5$ years to $6.4 \pm 3.1$ for $>15$ years.

Conclusion: The frequency of $\mathrm{HE}$ was higher in diabetic patients without other obvious precipitating factor. Patients with uncontrolled diabetes and patients on oral hypoglycemic drugs, and those with longer duration of diabetes seem to have higher risk of developing HE.

\section{INTRODUCTION}

Hepatic encephalopathy (HE) is a complex and variable neuropsychiatric syndrome that is seen in patients with acute and chronic liver diseases [1]. The presence or severity of HE does not always show a strong and consistent relationship with the severity of liver disease or portal hypertension suggesting that other predisposing or precipitating factors may be involved [2]. It has been suggested that DM may contribute to the presence and severity of $\mathrm{HE}$ independent of the severity of liver disease in patients with HCV cirrhosis [3].

Diabetes mellitus is very common in the cirrhotic population because of shared etiologies such as obesity, chronic HCV, iron overload, and alcohol as well as insulin resistance associated with cirrhosis [4]. Diabetes mellitus is more prevalent in patients with post-hepatitis $\mathrm{C}$ cirrhosis than in those with cirrhosis due to other etiologic agents [5]. 
There are many factors that precipitate $\mathrm{HE}$ in patients with cirrhosis including constipation, gastrointestinal bleeding, dietary protein overload, electrolyte abnormalities (hypokalemia, azotemia), medications (opiates, benzodiazepines, and anti-psychotic agents), and infections. Usually $\mathrm{HE}$ is reversible in this situation when the precipitating factors are eliminated or corrected. The presence of DM may be another factor in the pathogenesis of $\mathrm{HE}$ at least in patients with $\mathrm{HCV}$ cirrhosis [6].

An increased ammonia level of gut bacterial origin is an important mediator in the pathogenesis of hepatic encephalopathy (HE), and constipation is a frequent precipitant of hepatic coma. Because diabetes mellitus (DM) may be associated with delayed gastrointestinal transit, we speculated that its presence in patients with HCV-related cirrhosis would predispose to and exacerbate HE [6]. Diabetes mellitus and insulin resistance are characterized by releasing and enhancing proinflammatory cytokines. Type 2 diabetes mellitus could impair hepatic encephalopathy by different mechanisms that include: a) increasing glutaminase activity; b) impairing gut motility and promoting constipation, intestinal bacterial overgrowth and bacterial translocation [7].

This study aimed at evaluating if diabetes mellitus has impact on the incidence of hepatic encephalopathy in patients with severely decompensated liver disease. This study aimed also to evaluate the effect of diabetes control and the drugs used to achieve control on the incidence and severity if hepatic encephalopathy.

\section{PATIENTS AND METHODS}

This study was conducted in Tropical Medicine Department in Zagazig University Hospitals. The present study included 264 post-HCV liver cirrhosis patients. Patients were categorized into 2 groups:

- Group I (test): post-HCV liver cirrhosis with diabetes mellitus (132 patients).

- Group II (control): post-HCV liver cirrhosis without diabetes (132 patients).

\section{Inclusion criteria:}

Patients who have post-HCV liver cirrhosis with severely decompensated liver disease (Child's grade $\mathrm{C}$ ) with and without diabetes mellitus were included in this study.

\section{Exclusion criteria:}

- Patients with renal impairment or renal medical disease.

- Patients with malignancies.

- Patients with SBP.

- Patients with Child's grade A or B.

- Patients with cirrhosis due to causes other than $\mathrm{HCV}$ e.g. HBV, autoimmune, metabolic or alcoholic.

- Patients with type I diabetes.

All patients were subjected to the following:

- Complete history taking with special stress on:

- Past history of frequency and severity of hepatic encephalopathy,

- Duration of DM.

- Drugs used for control of DM

- Precipitating factors of encephalopathy

- Thorough clinical examination

- Psychometric testing for HE

- The following laboratory investigations:

- Complete blood count, liver function test, kidney function test, prothrombin time, INR, serum uric acid, fasting and postprandial blood glucose.

- Glycosylated haemoglobin level: The reference range for healthy adults is 4.85.9\%.The decision limits for non-pregnant adults, according to the American Diabetes Association, are as follows: For patients with $\mathrm{DM}$, the goal of therapy is less than $7.0 \%$.The diagnostic criterion for diabetes is greater than or equal to $6.5 \%$ National Glycohemoglobin Standardization Program (NGSP) units [8].

- Viral markers

- Autoimmune markers: ANA, SMA, antiLKM

- Bilharzial Antibody titre

- Imaging investigations: Abdominal Ultrasound

\section{Statistical analysis:}

Data were expressed as mean \pm SD for quantitative data and number and percentage for qualitative data and comparison was done by Standard normal deviate $(\mathrm{Z})$ for the quantitative data and Chisquare test $\left(\mathrm{X}^{2}\right)$ for categorical and qualitative data and ANOVA $(\mathrm{F})$ for multivariate analysis. 


\section{RESULTS}

There were no significant differences between the two studied groups as regards demographic data, hematological parameters, coagulation profile, uric acid as well as liver and kidney function tests. There were also no significant differences as regards the prevalence of ascites among both groups as well as mean splenic size and portal vein diameter as shown in tables $(1,2,3)$. Table 4 shows that patients with diabetes and cirrhosis (group I) had significantly higher incidence of hepatic encephalopathy of all grades than non-diabetic cirrhotic patients (group II) also it shows patients of group I had higher mean number of attacks during the last three months than patients in group II. Comparison of the precipitating factors of the attacks showed that there is higher incidence of unknown precipitating factor among patients of group I as shown in table 5.
Table (6) shows that $42 \%$ of patients using oral hypoglycemic had hemoglobin A1c level higher than $11 \mathrm{~g} / \mathrm{dl}$ the finding that refers to failure of control associated with the use of oral hypoglycemic drugs. Also, there was higher incidence of encephalopathy of all grades among patients receiving oral hypoglycemic drugs than those receiving insulin for control of diabetes in group I as shown in table 7.

Patients of group I with different levels of HBA1c had no significant difference as regards the incidence of different grades of encephalopathy. However, the mean number of attacks experienced by each patient in group I rises significantly with higher levels of HBA1c as shown in table 8 . Patients with diabetes for longer than 15 years among patients of group I had significantly higher incidence of severe encephalopathy grade III and IV. Also, the mean number of attacks for each patient rises significantly with longer duration of diabetes as shown in table 9.

Table (1): Patients characteristics of the studied group

\begin{tabular}{|c|c|c|c|c|c|c|c|c|}
\hline & \multicolumn{2}{|c|}{$\begin{array}{l}\text { Group I } \\
\text { No=132 }\end{array}$} & \multicolumn{2}{|c|}{$\begin{array}{c}\text { Group II } \\
\text { No=132 }\end{array}$} & \multirow{2}{*}{$\begin{array}{c}\text { Test } \\
\text { value }\end{array}$} & \multirow[t]{2}{*}{$\mathbf{P}$} & \multirow[t]{2}{*}{ Sig. } \\
\hline & & No & $\%$ & No & $\%$ & & & \\
\hline \multirow[b]{2}{*}{ Sex } & Male & 58 & 43.9 & 70 & 53.0 & \multirow{2}{*}{$X^{2}=2.18$} & \multirow{2}{*}{0.139} & \multirow{2}{*}{ NS } \\
\hline & Female & 74 & 56.1 & 62 & 47.0 & & & \\
\hline \multicolumn{2}{|c|}{$\begin{array}{l}\text { Age (years) } \\
\text { Mean } \pm \text { SD }\end{array}$} & \multicolumn{2}{|c|}{$57.1 \pm 7.4$} & \multicolumn{2}{|c|}{$55.5 \pm 7.1$} & $\mathrm{t}=1.789$ & 0.075 & NS \\
\hline
\end{tabular}

Table (2): Comparison between Group I and Group II as regard CBC, Coagulation profile, liver and kidney function tests and uric acid level

\begin{tabular}{|l|c|c|c|c|c|}
\hline & $\begin{array}{c}\text { Group I } \\
\text { No.=132 }\end{array}$ & $\begin{array}{c}\text { Group II } \\
\text { No.=132 }\end{array}$ & $\mathbf{Z}$ & P & Sig. \\
\hline HB (g/dl) Mean \pm SD & $10 \pm 1.2$ & $9.9 \pm 1.1$ & 0.753 & 0.452 & NS \\
\hline WBC (cellsx10\%/uL) Mean \pm SD & $6.6 \pm 1.7$ & $6.5 \pm 1.7$ & 0.305 & 0.761 & NS \\
\hline PLT (cellsx10\%/uL) Mean \pm SD & $83.9 \pm 30.4$ & $85.2 \pm 31$ & 0.363 & 0.717 & NS \\
\hline PT (sec) Mean \pm SD & $23.9 \pm 5.4$ & $25 \pm 5.1$ & 1.621 & 0.106 & NS \\
\hline PC (\%) Mean \pm SD & $41.6 \pm 11$ & $39.9 \pm 12$ & 1.44 & 0.231 & NS \\
\hline INR Mean \pm SD & $2.3 \pm 1.5$ & $2.4 \pm 1.5$ & 0.489 & 0.619 & NS \\
\hline ALT(IU/L) Mean \pm SD & $46.7 \pm 22.7$ & $48.9 \pm 23$ & 0.682 & 0.496 & NS \\
\hline AST(IU/L) Mean \pm SD & $82.3 \pm 41.7$ & $82.8 \pm 40$ & 0.078 & 0.938 & NS \\
\hline Albumin (g/dl) Mean \pm SD & $2.2 \pm 0.4$ & $2.1 \pm 0.4$ & 1.735 & 0.084 & NS \\
\hline T.bil (mg/dl) Mean \pm SD & $5.1 \pm 1.9$ & $5.3 \pm 2.1$ & 1.084 & 0.279 & NS \\
\hline D.bil (mg/dl) Mean \pm SD & $3.1 \pm 1.1$ & $3.3 \pm 1.2$ & 1.99 & 0.159 & NS \\
\hline Creatinine (mg/dl) Mean \pm SD & $0.8 \pm 0.2$ & $0.8 \pm 0.1$ & 0.123 & 0.902 & NS \\
\hline Uric acid (mg/dl) Mean \pm SD & $7.1 \pm 2.3$ & $6.9 \pm 2$ & 0.618 & 0.537 & NS \\
\hline
\end{tabular}


Table (3): Comparison between Group I and Group II as regard U/S

\begin{tabular}{|c|c|c|c|c|c|c|c|c|}
\hline & \multicolumn{2}{|c|}{$\begin{array}{l}\text { Group I } \\
\text { No.=132 }\end{array}$} & \multicolumn{2}{|c|}{$\begin{array}{l}\text { Group II } \\
\text { No.=132 }\end{array}$} & \multirow[t]{2}{*}{ Test value } & \multirow[t]{2}{*}{$\mathbf{P}$} & \multirow[t]{2}{*}{ Sig. } \\
\hline & & No. & $\%$ & No. & $\%$ & & & \\
\hline \multirow{2}{*}{ Ascites } & Absent & 6 & 4.5 & 7 & 5.3 & \multirow{2}{*}{$X^{2}=0.08$} & \multirow{2}{*}{0.776} & \multirow{2}{*}{ NS } \\
\hline & Detected & 126 & 95.5 & 125 & 94.7 & & & \\
\hline \multicolumn{2}{|c|}{ PVD (mm) Mean \pm SD } & \multicolumn{2}{|c|}{$14.9 \pm 1.3$} & \multicolumn{2}{|c|}{$15 \pm 1.1$} & $\mathrm{Z}=0.674$ & 0.501 & $\mathrm{NS}$ \\
\hline \multicolumn{2}{|c|}{ Spleen size $(\mathrm{cm})$ Mean \pm SD } & \multicolumn{2}{|c|}{$16.2 \pm 1.5$} & \multicolumn{2}{|c|}{$16.3 \pm 1.4$} & $\mathrm{Z}=0.33$ & 0.742 & NS \\
\hline
\end{tabular}

Table (4): Comparison between Group I and Group II as regard assessment of Encephalopathy in the last 3 months

\begin{tabular}{|c|c|c|c|c|c|c|c|c|}
\hline & & \multicolumn{2}{|c|}{$\begin{array}{l}\text { Group I } \\
\text { No.=132 } \\
\end{array}$} & \multicolumn{2}{|c|}{$\begin{array}{l}\text { Group II } \\
\text { No.=132 }\end{array}$} & \multirow[t]{2}{*}{ Test value } & \multirow[t]{2}{*}{$\mathbf{P}$} & \multirow[t]{2}{*}{ Sig. } \\
\hline & & No. & $\%$ & No. & $\%$ & & & \\
\hline \multicolumn{2}{|l|}{ (+ve) Psychometric test } & 9 & 6.8 & 4 & 3.0 & $\chi^{2} 2.02$ & 0.154 & $\mathrm{NS}$ \\
\hline \multirow{4}{*}{ Grade of encephalopathy } & G1 & 47 & 35.6 & 35 & 26.5 & \multirow[t]{4}{*}{$\chi^{2} 17.23$} & \multirow[t]{4}{*}{$<0.001$} & \multirow[t]{4}{*}{$\mathrm{HS}$} \\
\hline & $\mathrm{G} 2$ & 45 & 34.1 & 31 & 23.5 & & & \\
\hline & G3 & 29 & 22.0 & 19 & 14.4 & & & \\
\hline & G4 & 22 & 16.7 & 18 & 13.6 & & & \\
\hline \multicolumn{2}{|c|}{$\begin{array}{l}\text { No. of attacks/each patient } / 3 \text { mo } \\
\text { Mean } \pm \text { SD }\end{array}$} & \multicolumn{2}{|c|}{$1.9 \pm 0.3$} & \multicolumn{2}{|c|}{$0.8 \pm 0.1$} & $Z=5.063$ & $<0.001$ & HS \\
\hline
\end{tabular}

Table (5): Comparison between the two groups as regards precipitating factors of hepatic encephalopathy

\begin{tabular}{|l|c|c|c|c|c|c|c|}
\hline \multirow{2}{*}{\multicolumn{1}{|c|}{ Precipitating factors }} & \multicolumn{2}{|c|}{$\begin{array}{c}\text { Group I } \\
\text { No=132 }\end{array}$} & \multicolumn{2}{c|}{$\begin{array}{c}\text { Group II } \\
\text { No=132 }\end{array}$} & \multirow{2}{*}{$\mathbf{X}^{\mathbf{2}}$} & \multirow{2}{*}{ P } & \multirow{2}{*}{ Sig. } \\
\cline { 2 - 5 } & $\mathbf{N o}$ & $\mathbf{\%}$ & $\mathbf{N o}$ & $\mathbf{\%}$ & & & \\
\hline Constipation & 25 & 18.9 & 17 & 12.9 & 1.81 & 0.178 & NS \\
\hline Protein diet & 8 & 6.1 & 10 & 7.6 & 0.24 & 0.625 & NS \\
\hline Diuretics & 14 & 10.6 & 15 & 11.4 & 0.04 & 0.843 & NS \\
\hline Hematemesis and/or melena & 6 & 4.5 & 12 & 9.1 & 2.15 & 0.142 & NS \\
\hline Tapping & 1 & 0.8 & 3 & 2.3 & 1.02 & 0.314 & NS \\
\hline Gastroenteritis & 3 & 2.3 & 7 & 5.3 & 1.66 & 0.197 & NS \\
\hline Chest infection & 18 & 13.6 & 13 & 9.8 & 0.91 & 0.393 & NS \\
\hline UTI & 19 & 14.4 & 18 & 13.6 & 0.03 & 0.859 & NS \\
\hline Unknown cause & 58 & 43.9 & 22 & 16.7 & 23.24 & $<0.001$ & HS \\
\hline
\end{tabular}

Table (6): Correlation between anti diabetic drugs and HBA1C in group I

\begin{tabular}{|c|c|c|c|c|c|c|c|}
\hline \multirow{2}{*}{$\begin{array}{c}\text { HBA1c level \% } \\
\text { NGSP units }\end{array}$} & \multicolumn{2}{|c|}{$\begin{array}{c}\text { Oral } \\
\text { hypoglycemics } \\
\text { No= 19 }\end{array}$} & \multicolumn{2}{c|}{$\begin{array}{c}\text { Insulin } \\
\text { No= 113 }\end{array}$} & \multirow{2}{*}{$\mathbf{X}^{\mathbf{2}}$} & \multirow{2}{*}{ P } & \multirow{2}{*}{ Sig. } \\
\cline { 2 - 5 } & $\mathbf{N o}$ & $\mathbf{\%}$ & $\mathbf{N o}$ & $\mathbf{\%}$ & & & \\
\hline$<7$ & 1 & 5.3 & 10 & 8.8 & 0.27 & 0.6 & NS \\
\hline $7-9$ & 4 & 21.1 & 43 & 38.1 & 2.05 & 0.152 & NS \\
\hline $9-11$ & 6 & 31.6 & 36 & 31.9 & 0.06 & 0.809 & NS \\
\hline$>11$ & 8 & 42.1 & 24 & 21.2 & 3.86 & 0.049 & S \\
\hline
\end{tabular}


Table (7): Correlation between encephalopathy and anti-diabetic drugs in group I

\begin{tabular}{|l|c|c|c|c|c|c|c|}
\hline \multirow{2}{*}{} & \multicolumn{2}{|c|}{$\begin{array}{c}\text { Oral hypoglycemic } \\
\text { drugs } \\
\text { No= 19 }\end{array}$} & \multicolumn{2}{c|}{$\begin{array}{c}\text { Insulin } \\
\text { No= 113 }\end{array}$} & \multirow{2}{*}{$\mathbf{X}^{\mathbf{2}}$} & P & Sig. \\
\cline { 2 - 5 } & No & \% & No & \% & & & \\
\hline Psycho +ve & 6 & 31.6 & 3 & 2.7 & 21.42 & $<0.001$ & HS \\
\hline Grade I & 8 & 42.1 & 12 & 10.6 & 12.54 & $<0.001$ & HS \\
\hline Grade II & 12 & 63.2 & 19 & 16.8 & 19.44 & $<0.001$ & HS \\
\hline Grade III & 15 & 78.9 & 25 & 22.1 & 24.87 & $<0.001$ & HS \\
\hline Grade IV & 19 & 100.0 & 33 & 29.2 & 34.15 & $<0.001$ & HS \\
\hline
\end{tabular}

Table (8): Correlation between encephalopathy and HBA1C in group I

\begin{tabular}{|c|c|c|c|c|c|c|c|c|c|c|c|}
\hline \multirow{4}{*}{$\begin{array}{c}\text { Grades of } \\
\text { encephalopathy }\end{array}$} & \multicolumn{8}{|c|}{ HBA1c level (g/dl) } & \multirow{4}{*}{$\mathbf{X}^{2}$} & \multirow{4}{*}{$\mathbf{P}$} & \multirow{4}{*}{ Sig. } \\
\hline & \multirow{2}{*}{\multicolumn{2}{|c|}{$\begin{array}{c}<7 \\
\text { No }=11 \\
\end{array}$}} & \multirow{2}{*}{\multicolumn{2}{|c|}{$\begin{array}{c}7-9 \\
\text { No }=47\end{array}$}} & \multirow{2}{*}{\multicolumn{2}{|c|}{$\frac{9-11}{\text { No }=42}$}} & \multirow{2}{*}{\multicolumn{2}{|c|}{$\begin{array}{c}>11 \\
\text { No=32 }\end{array}$}} & & & \\
\hline & & & & & & & & & & & \\
\hline & No & $\%$ & No & $\%$ & No & $\%$ & No & $\%$ & & & \\
\hline Psycho +ve & 0 & 0.0 & 2 & 4.3 & 5 & 11.9 & 2 & 6.3 & 3.02 & 0.389 & NS \\
\hline Grade I & 5 & 45.5 & 7 & 14.9 & 4 & 9.5 & 5 & 15.6 & 2.72 & 0.48 & NS \\
\hline Grade II & 4 & 36.3 & 8 & $\overline{17.0}$ & 7 & 16.7 & 9 & 28.1 & 3.44 & 0.33 & NS \\
\hline Grade III & 5 & 45.5 & 11 & 23.4 & 13 & 30.9 & 11 & 34.4 & 2.51 & 0.473 & $\mathrm{NS}$ \\
\hline Grade IV & 5 & 45.5 & 10 & 21.3 & 14 & 33.3 & 15 & 46.9 & 6.44 & 0.0992 & $\mathrm{NS}$ \\
\hline $\begin{array}{l}\text { No of attacks/ } \\
\text { patient Mean } \pm \text { SD }\end{array}$ & \multicolumn{2}{|c|}{$0.8 \pm 0.2$} & \multicolumn{2}{|c|}{$3.4 \pm 1.1$} & \multicolumn{2}{|c|}{$5 \pm 2.2$} & \multicolumn{2}{|c|}{$6.4 \pm 3$} & $\mathrm{~F}=7.2$ & $<0.001$ & HS \\
\hline
\end{tabular}

Table (9): Correlation between encephalopathy and duration of diabetes in group I

\begin{tabular}{|c|c|c|c|c|c|c|c|c|c|c|c|}
\hline & \multicolumn{8}{|c|}{ Duration of diabetes in years } & \multirow{4}{*}{$\mathbf{X}^{2}$} & \multirow{4}{*}{$\mathbf{P}$} & \multirow{4}{*}{ Sig. } \\
\hline \multirow{3}{*}{$\begin{array}{c}\text { Grades of } \\
\text { hepatic } \\
\text { encephalopathy }\end{array}$} & \multirow{2}{*}{\multicolumn{2}{|c|}{$\begin{array}{l}<5 \text { years } \\
\text { No=48 }\end{array}$}} & \multirow{2}{*}{\multicolumn{2}{|c|}{$\begin{array}{c}5-10 \\
\mathrm{No}=33\end{array}$}} & \multirow{2}{*}{\multicolumn{2}{|c|}{$\begin{array}{l}10-15 \\
\text { No=29 }\end{array}$}} & \multirow{2}{*}{\multicolumn{2}{|c|}{$\begin{array}{c}>15 \\
\text { No=22 }\end{array}$}} & & & \\
\hline & & & & & & & & & & & \\
\hline & No & $\%$ & No & $\%$ & No & $\%$ & No & $\%$ & & & \\
\hline Psycho +ve & 1 & 2.1 & 3 & 9.1 & 3 & 10.3 & 2 & 9.1 & 2.71 & 0.439 & $\mathrm{NS}$ \\
\hline Grade I & 7 & $\overline{14.6}$ & 5 & $\overline{15.2}$ & 6 & 20.7 & 7 & 31.8 & 3.34 & 0.343 & $\mathrm{NS}$ \\
\hline Grade II & 5 & 10.4 & 8 & 24.2 & 9 & 31.0 & 10 & 45.5 & 11.11 & 0.011 & $\mathrm{~S}$ \\
\hline Grade III & 6 & 12.5 & 9 & 27.3 & 11 & 37.9 & 13 & 59.1 & 16.99 & $<0.001$ & $\mathrm{HS}$ \\
\hline Grade IV & 4 & 8.3 & 11 & 33.3 & 15 & 51.7 & 17 & 77.3 & 35.59 & $<0.001$ & $\mathrm{HS}$ \\
\hline $\begin{array}{l}\text { No of attacks/ } \\
\text { patient Mean } \pm \\
\text { SD }\end{array}$ & & \pm 0.4 & & \pm 0.9 & & \pm 2.1 & & $7 \pm 3.1$ & $\mathrm{~F}=8.32$ & $<0.001$ & HS \\
\hline
\end{tabular}




\section{DISCUSSION}

This study was designed to detect the effect of diabetes itself, its duration, its control and the drugs used to achieve this control on the severity and the frequency of the hepatic encephalopathy encountered by patients with severely decompensated liver cirrhosis due to $\mathrm{HCV}$. HCV seems to have a strong relation with diabetes. Most of the previous literature says that the diabetes and insulin resistance associated steatosis can hasten the progression of $\mathrm{HCV}$ related liver damage and HCV can induce insulin resistance in patients with chronic hepatitis $\mathrm{C}$.

In this study the diabetic patients group had no significant difference from non-diabetics as regards age, gender as well as the entire routine laboratory parameters. This finding indicates that the deterioration of the liver function was not the only risk factor that causes the higher frequency of hepatic encephalopathy of all grades noticed in patients of the diabetic group. This is in agreement with Sigal et al. who said that patients with diabetes tend to develop encephalopathy even with milder liver decompensation. The frequency of encephalopathy attacks in the past three months is also significantly higher in diabetic patients [6].

In this study we focused on the history of the possible precipitating factor for encephalopathy attacks like protein diet, constipation, tapping for ascites and diuretics, gastroenteritis, urinary tract and chest infections and upper GIT bleeding. If the history taking revealed unknown mode of precipitation we also mentioned it as an attack with unknown precipitating factor. We found that the patients with diabetes had significantly higher frequency of unknown mode of precipitation (43\%) compared to non-diabetic patients (23\%). Although diabetes is associated with higher risk of infection, infection doesn't seem to take the upper hand as a precipitating factor. This agrees with Ampuero et al. who said that patients with diabetes showed raised risk of overt hepatic encephalopathy in comparison with non-diabetics because type 2 diabetes mellitus could impair hepatic encephalopathy by different mechanisms that include: a) increasing glutaminase activity; b) impairing gut motility and promoting constipation, intestinal bacterial overgrowth and bacterial translocation [7]. This is also agreed with by Thuluvath [9] who said that diabetes causes autonomic neuropathy that affects the motility of the gut leading to excess ammonia production.

Asking the patients about the medication they use to control diabetes revealed that a small percent of them use different types of oral hypoglycemic drugs (14\%). This small percent of patient had high frequency of all grades of HE. This is in disagreement with Ampeuro et al. who found that metformin decreases the frequency of encephalopathy by decreasing the production of glutamine [10]. This disagreement may be due to the use of different types of oral hypoglycemic including metformin by patients in our study rather than focus on metformin only like in Ampuero et al. study.

In this study, we also noticed that $42 \%$ of patients on oral hypoglycemic had HBA1c level above $11 \%$ NGSP units a mark of bad control of diabetes over the last three months, and about 5 $\%$ of them only managed to achieve the target of less than $7 \%$. This finding says that the increased frequency may be related to the bad control of diabetes. This finding also confirms that the patients on insulin had a better chance for managing and controlling diabetes than those on oral hypoglycemic. The glycosylated hemoglobin gives us an idea about the control of diabetes in the last three months. In our study, we investigated about the number and the severity of attacks of hepatic encephalopathy during the past three months to be able to link it to the diabetes control in this period. In this study, we also noticed that $42 \%$ of patients on oral hypoglycemic versus $21 \%$ of patients on insulin had HBA1c level above 11\% NGSP units as a mark of bad control of diabetes over the last three months, and about $5 \%$ of patients on oral hypoglycemic versus about $9 \%$ of patients on insulin managed to achieve the target of less than $7 \%$ NSGP units. This finding confirms that the patients on insulin had a better chance for managing and controlling diabetes than those on oral hypoglycemic. It is also clear that the increased frequency of hepatic encephalopathy with oral hypoglycemic use is related to the bad control of diabetes rather than oral hypoglycemic drugs themselves. This finding agrees with Gundling et al 2013 who studied different types of oral hypoglycemic drugs with liver cirrhosis versus insulin and concluded that glycemic control was insufficient in $73 \%$ of the patients receiving insulin therapy versus $88 \%$ of patients receiving oral antidiabetic drugs.[11] 
Comparing the frequency of different grades of $\mathrm{HE}$ in diabetic patients with variable levels of HBA1c showed that there was no significant difference in the frequency of all grades of HE. However, the number of attacks experienced by each patient during the past three months increases with the increase in the level of glycosylated hemoglobin. This also confirms that the increased frequency of $\mathrm{HE}$ associated with oral hypoglycemic drugs use is related to the failure of control rather than the use of those drugs itself. This finding agrees with that in the study by Gundling et al. who said that patients achieving satisfactory control experienced a

lower rate of certain cirrhosis-related complications such as hepatic encephalopathy (HE) [HE 36.6\% (diabetics) vs. $20.7 \%$ (non-diabetics][11].

In our study we also tried to find the relation of the duration of diabetes to the severity and frequency of HE. We found that patients with longer duration of diabetes exceeding 15 years have higher frequency of attacks of severe encephalopathy (grade II and IV). Also, we found that the number of attacks experienced by each patient during the past three months increases with the increase in the duration of diabetes. This is in agreement with Nathan et al, 2005 who said that the longer the duration of diabetes the more profound the changes in the nerve tissues and their blood supply. We can also say that patient with long duration of diabetes must have been experiencing cumulative brain and nerve tissue damage through this long period that make these patients more liable to severe and more frequent attacks of hepatic coma [12].

\section{CONCLUSION:}

The frequency of HE was higher in diabetic decompensated liver diseased patients without obvious precipitating factor. Patients on oral hypoglycemic drugs, patients with uncontrolled diabetes and patients with longer duration of diabetes seem to have higher risk of developing HE.

\section{REFERENCES}

1- Davi G, Falco A, Patrono C: Lipid peroxidation in diabetes mellitus. Antioxid Redox Signal 2005; 7 : 256-68.

2- Bloch-Dam IA, Bashan N: Proposed mechanisms for the induction of insulin resistance by oxidative stress. Antioxid Redox Signal 2005; 7:1553-67.
3- Kaneto H, Nakatani Y, Kawamori D, Miyatsuka T, Matsuoka TA, Matsuhisa $M$ et al: Role of oxidative stress, endoplasmic reticulum stress, and c-Jun N-terminal kinase in pancreatic beta-cell dysfunction and insulin resistance. Int J Biochem. Cell Biol 2006; 38:782-93.

4- Lonardo A, Adinolfi LE, Petta S, Craxì A, Loria P: Hepatitis C and diabetes: the inevitable coincidence? Expert Rev Anti Infect Ther. 2009;7(3):293-308.

5- Garrido Serrano A, Guerrero Igea FJ, Lepe Jiménez JA, Palomo Gil S, Grilo Reina A: Hyperinsulinemia in cirrhotic patients infected with hepatitis $\mathrm{C}$ virus. Gastroenterol Hepatol. 2001; 24(3):127-31.

6- Sigal SH, Stanca CM, Kontorinis N, Bodian C, Ryan E: Diabetes mellitus is associated with hepatic encephalopathy in patients with $\mathrm{HCV}$ cirrhosis. Am J Gastroenterol. 2006;101(7):14906.

7- Ampuero J, Ranchal I, del Mar Díaz-Herrero M, del Campo JA, Bautista JD, Romero-Gómez M: Role of diabetes mellitus on hepatic encephalopathy. Metab Brain Dis 2013; 28(2): 277-9.

8- Sidorenkov G, Haaijer-Ruskamp FM, de Zeeuw D, Denig P: A longitudinal study examining adherence to guidelines in diabetes care according to different definitions of adequacy and timeliness. PloS One 2011; 6(9): e24278.

9- Thuluvath PJ: Higher prevalence and severity of hepatic encephalopathy in patients with $\mathrm{HCV}$ cirrhosis and diabetes mellitus: is presence of autonomic neuropathy the missing part of the puzzle? Am J Gastroenterol. 2006;101(10):2244-6.

10- Ampuero J, Ranchal I, Nuñez D, Díaz-Herrero Mdel M, Maraver M, del Campo JA, et al: Metformin inhibits glutaminase activity and protects against hepatic encephalopathy. Plos One 2012; 7(11):e49279

11-Gundling F1, Seidl H, Strassen I, Haller B, Siegmund T, Umgelter A et al: Clinical manifestations and treatment options in patients with cirrhosis and diabetes mellitus. Digestion. 2013; 87(2):75-84.

12- Nathan DM, Cleary PA, Backlund JY, Genuth SM, Lachin JM, Orchard TJ et al.: Intensive diabetes treatment and cardiovascular disease in patients with type 1 diabetes. $N$ Engl J Med. 2005; $22 ; 353(25): 2643-53$.

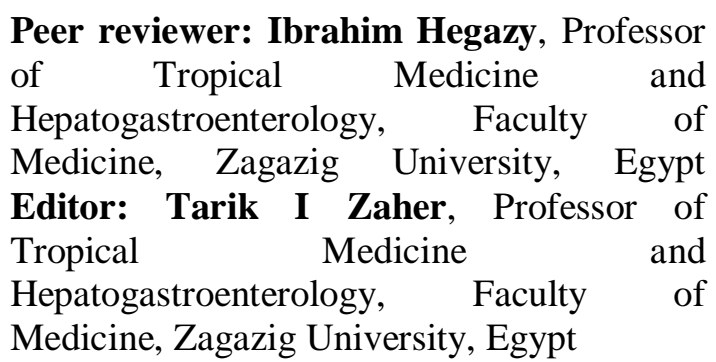
www.mis.zu.edu.eg/ajied/home.aspx 